\title{
Impacts of temperature alteration on the drinking water quality stored in plastic bottles
}

\author{
Abdelkader T. Ahmed ${ }^{1,2}$ (D) Mohammed Emad ${ }^{3} \cdot$ Mohammed A. Bkary $^{4}$
}

Received: 8 February 2021 / Accepted: 16 September 2021 / Published online: 24 September 2021

(c) The Author(s) 2021

\begin{abstract}
Many people prefer to drink bottled water instead off the tap water. The bottled water is stored in the plastic bottles sometimes for long time. These plastic bottles might leach out some harmful materials into the water especially when exposed to temperature alteration, which may affect human health. This research work focused on investigating the effect of changing temperature on the bottled water quality. The work studied the effect of heating water in plastic bottles by sun, oven, and microwave. The study included also the impact of cooling and freezing the bottled waters. Results showed that temperature alterations caused changes in some physicochemical properties of bottled waters such as decreasing the values of $\mathrm{pH}$ and TDS and increasing levels of fluoride and chloride. In addition, the concentration levels of some physiochemical parameters exceeded the permissible values for drinking water. With temperature alterations, all levels of heavy metals in bottled waters were minimal except some small concentrations of copper and zinc. Results confirmed also differences in behavior between the bottled water brands exposed to the same temperature alterations. Heating bottled waters above $50{ }^{\circ} \mathrm{C}$ is alarming problem on the water quality. This is because above this degree, many alternations were observed in the water content. The outcomes of this work are useful for improving the current legislation on bottled waters and their storage.
\end{abstract}

Keywords Drinking water $\cdot$ Water quality $\cdot$ Temperature alteration $\cdot$ Bottled water $\cdot$ Plastic bottles

\section{Introduction}

Clean and safe drinking water is an essential element of health security and strengthens sustainable social and economic development (WHO 2011). Many people do not drink directly tap water. They prefer to drink bottled water, which is filled, from groundwater or sometimes-surface water with or without some treatment process such as filtration and sterilization. This water is stored normally in plastic bottles for long time, i.e., six months up to a year. These plastic bottles may expose to temperature alterations and might

Abdelkader T. Ahmed

dratahmed@yahoo.com

1 Civil Engineering Department, Faculty of Engineering, Islamic University, Al-Madinah, Kingdom of Saudi Arabia

2 Civil Engineering Department, Faculty of Engineering, Aswan University, Aswan, Egypt

3 Chemistry Department, Faculty of Science, Islamic University, Al-Madinah, Kingdom of Saudi Arabia

4 Research Management and Environmental Laboratories, Al-Madinah, Kingdom of Saudi Arabia leach out some harmful materials into the water, which may affect human health. For example, Bisphenol A (BPA) is an organic synthetic compound commonly used in manufacturing plastic bottles. If this compound leaches out into the water may cause many diseases such as diabetes, high blood pressure, and cancer (Taylor-Smith 2020).

On the other hand, bottled water is getting popularity in many countries including Saudi Arabia despite the excessively high price compared to tap water. Bottled water is filled mainly from this natural source or sometimes from treated tap water. Two principal features of groundwater bodies distinguish them from surface water bodies. Firstly, the relatively slow movement of water through the ground means that residence times in groundwaters are generally orders of magnitude longer than in surface waters. Once polluted, a groundwater body could remain so for decades, or even for hundreds of years, because the natural processes of through-flushing are so slow. Secondly, there is a considerable degree of physicochemical and chemical interdependence between the water and the containing material. The word groundwater, without further qualification, is generally understood to mean all the water underground, occupying 
the voids within geological formations. It follows, therefore, that in dealing with groundwater, the properties of both the ground and the water are important, and there is considerable scope for water quality to be modified by interaction between the two. The scope for such combination is in turn enhanced by the long residence times, which depend on the size and type of the groundwater body and the flow properties as well (Chilton 1996).

Thus, it is necessary to assess the quality of bottled water due to its source in concern of public health. Bottled water could be one of the sources for supply of toxic trace metals, heavy metals, and radionuclide. While the dissolved radionuclide and minerals allegedly instill medicinal benefits in persons who drink the water, consumption contributes to the body intake of these constituents. The abundance of toxic chemicals, radionuclide, nitrites, and nitrates in drinking water may cause adverse effects on the human health such as cancer, other human body malfunctions and chronic illnesses. There may be considerable risk to humans, especially children exposed to bottled water containing toxic elements and microbiological entities (Oyebog et al. 2012). In Riyadh, KSA, A study was done to determine the water quality of some commercial bottle waters from chemical components aspect (Khater et al. 2014). They conclude that most of the samples were complied with the Gulf quality standards except for $\mathrm{pH}$ value, TDS, SO4, and $\mathrm{F}$ in some samples.

The plastic bottles used normally for drinking water purposes contain several monomers and additives, such as stabilizers, antioxidants, catalyzers, and plasticizers (Bolgar et al. 2008). It was stated that antioxidants during polyethylene terephthalate (PET) manufacturing or during the washing steps of plastic containers could be interacted with water and released some constituents. (Bach et al. 2012). The oxygen presence associate with high temperatures in PET melt process can indorse many reactions such as thermomechanical or thermo-oxidative, which develops the migration of plastic material components into water. Guart et al. (2014) reported that the presence of gas (carbonated water) influences the migration of some plastic constituents due to the lower $\mathrm{pH}$ of water or their elimination during storage.

Some harmful trace materials might be released from the bottled water container. Plastic drinking bottles contain many chemicals, some of which interfere with hormones in the body (Taylor-Smith 2020). These chemicals include bisphenol A, or BPA, and phthalates, among others. Chemicals in the plastic can leach into bottled water, especially when exposed to heat or when the bottle is old. Different types of plastic indicated by the number inside the triangle of arrows on the bottom of the bottle-contain different chemicals. In addition, there might also a possibility to grow some pathogenic bacteria due to long time storage along with favorable environmental condition such as temperature and $\mathrm{pH}$ of the water, which may affects the public health (Zamberlan da Silva et al. 2008). In Madinah, there is one study examined some types of bacteria in drinking water and their impacts on human health (Al-Turk and Diab 2009). The study concluded that from bacteriological aspect, tap and bottled water are suitable for drinking. However, for underground well, water in some places, is not safe because it is affected by many factors such as anthropogenic pollution and the interface of water with surrounding rocks.

All previous studies examined the change of the temperature degree and time duration on the plastic leaching, no one, in the authors 'knowledge, studies the impact of different temperature sources such as heating by oven or microwave or even freezing water. This research work focused on investigating the effect of changing temperature on the quality of the water stored in plastic bottles. The work studied the impact of heating water in plastic bottles by sun, oven, and microwave. The study also included the impact of freezing water.

\section{Methods and materials}

\section{Water samples collection and experiments}

The study area is in Madinah, Saudi Arabia. Its climate condition in the summer is very hot, long, and arid; the winter is short, dry, and windy. The temperature is always high. The warmest month is August with an average maximum temperature of $43{ }^{\circ} \mathrm{C}$. The coldest month is January with an average maximum temperature of $24^{\circ} \mathrm{C}$. Twenty-two samples of bottled water of two brands were collected from the market in Madinah. These samples were analyzed using standard methods following the methods described by US Environmental Protection Agency (EPA 2021). Effect of oven, microwave heating, and sunlight exposure on physicochemical parameters were investigated. The study included heating water in the plastic bottles from room temperature, $20^{\circ}$ to 30,50 , and $70^{\circ}$ by three means namely sun, oven, and microwave. For sun exposing, heating for maximum 50 degree can be obtained. Some bottled water samples also be cooled up to freezing point and melted again. The exposing time varied from few minutes to the whole daytime as in the case of sun heating. The strategy adopted in the experiments is the reaching the designated temperature limit and then remove and test the sample. Expose samples for long period of time did not considered in this study. The study focused on the impact of the instant expose to the temperature degree.

Table 1 presents the schedule of the experiments for two bottled water brands namely B1 and B2. Physicochemical parameters such as $\mathrm{NO}_{2}^{-}, \mathrm{NO}_{3}, \mathrm{Cl}^{-}, \mathrm{SO}_{4}^{2}, \mathrm{Na}^{+}, \mathrm{Fe}^{2}, \mathrm{pH}$, TDS, Turbidity, hardness, and color of the bottled water 
Table 1 The experiment schedule

\begin{tabular}{|c|c|c|c|}
\hline Sample no. & Brand no. & Temp. $\left({ }^{\circ} \mathrm{C}\right)$ & Heating source \\
\hline S0 & B1 & 20 (control) & Room temperature \\
\hline S1 & B1 & 0 & Freezer \\
\hline $\mathrm{S} 2$ & B1 & 30 & Sun \\
\hline S3 & B1 & 40 & Sun \\
\hline S4 & B1 & 50 & Sun \\
\hline S5 & B1 & 30 & Microwave \\
\hline S6 & B1 & 50 & Microwave \\
\hline S7 & B1 & 70 & Microwave \\
\hline S8 & B1 & 30 & Oven \\
\hline S9 & B1 & 50 & Oven \\
\hline S10 & B1 & 70 & Oven \\
\hline S00 & $\mathrm{B} 2$ & 20 (control) & Room temperature \\
\hline S11 & B2 & 0 & Freezer \\
\hline $\mathrm{S} 12$ & B2 & 30 & Sun \\
\hline S13 & $\mathrm{B} 2$ & 40 & Sun \\
\hline S14 & $\mathrm{B} 2$ & 50 & Sun \\
\hline S15 & B2 & 30 & Microwave \\
\hline S16 & $\mathrm{B} 2$ & 50 & Microwave \\
\hline $\mathrm{S} 17$ & B2 & 70 & Microwave \\
\hline S18 & B2 & 30 & Oven \\
\hline S19 & B2 & 50 & Oven \\
\hline S20 & B2 & 70 & Oven \\
\hline
\end{tabular}

samples were investigated. Several heavy metals particularly Antinomy ions were also examined. TDS and $\mathrm{pH}$ in water samples were carried out using the Hach HQ40d electrode. The ions such as $\mathrm{NO}_{2}^{-}, \mathrm{NO}_{3}^{-}, \mathrm{SO}_{4}^{2}, \mathrm{~F}^{-}, \mathrm{Fe}^{2+}$ were measured by using $\mathrm{Hach}$ Spectrophotometer DR/5000. Flame photometry was used to measure the sodium $\left(\mathrm{Na}^{+}\right)$, while chloride $\left(\mathrm{Cl}^{-}\right)$, and total hardness were determined by using titration process. E-coli also was examined by counting test. All physicochemical and biological properties of the bottled water measured in this work compared with manufacturer's labeling reported on the bottles and were comparing with the guideline values (WHO 2011).

\section{Experimental results}

This work investigated the impact of temperature alteration on drinking water quality stored in plastic bottles. The following sections presented the results of these experiments for two bottled water brands in comparison to their behavior in the room temperature as a control level.

\section{Alterations in physiochemical properties}

The impact of temperature alteration was examined for many physicochemical characteristics of bottled water. Figure 1 presents $\mathrm{pH}$ value measurements at different heating degrees for brands B1 and B2. Results exhibited that a slight decrease occurs in $\mathrm{B} 1$, while a remarkable reduction was observed in B2. Some samples of B2 heated up to $50{ }^{\circ} \mathrm{C}$ showed $\mathrm{pH}$ values less than acceptable levels for drinking water. It is known that $\mathrm{pH}$ drops with raises temperature because as the temperature increases, molecular vibrations rise. Thus, it leads to ionize water and produces more $\mathrm{H}^{+}$ions and accordingly, the $\mathrm{pH}$ will decrease. Akharame et al. (2018) reported also that the $\mathrm{pH}$ of the bottled water samples decreased gradually with increasing exposure to sun heating. It worth mentioned that, the reduction rate recorded herein for $\mathrm{pH}$ in $\mathrm{B} 2$ was different from that of B1. This perhaps indicates to the impact of raw materials forming these plastic bottles and differences in the original contents of waters as shown later in Table 2. Cheng et al. (2010) stated that various companies may manufacture different quality levels of plastic bottles which may release different levels of ions even for plastic bottles made of the same recycling materials. On the other hand, freezing water for both brands
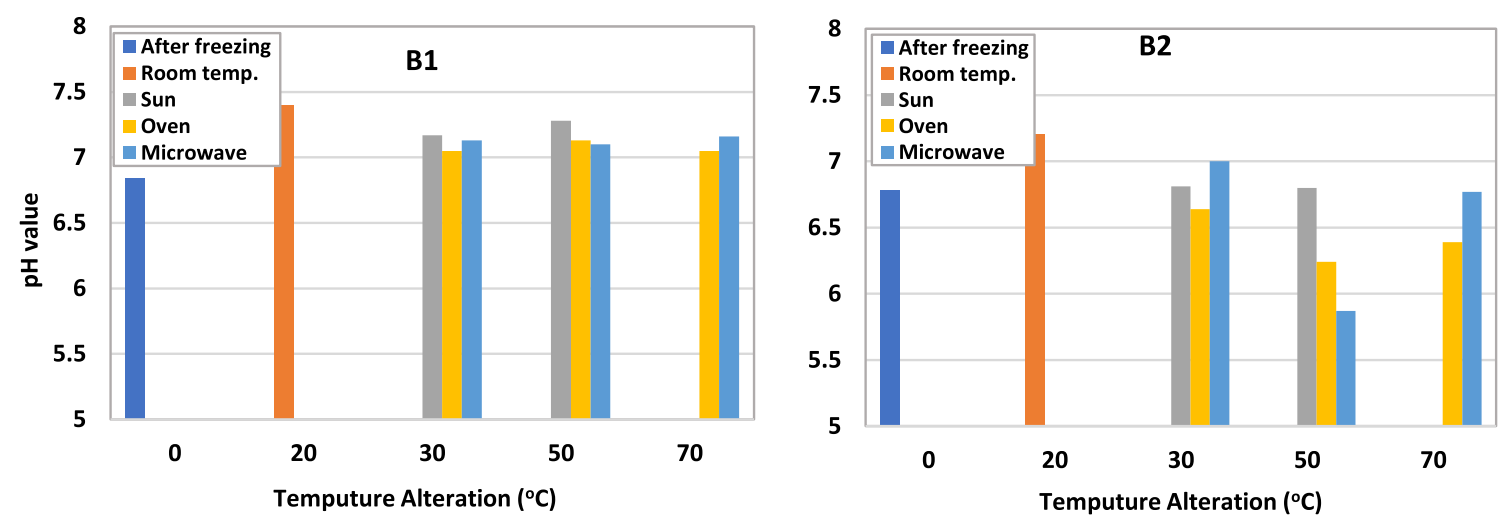

Fig. $1 \mathrm{pH}$ values at different heating degrees for brands B1 and B2 


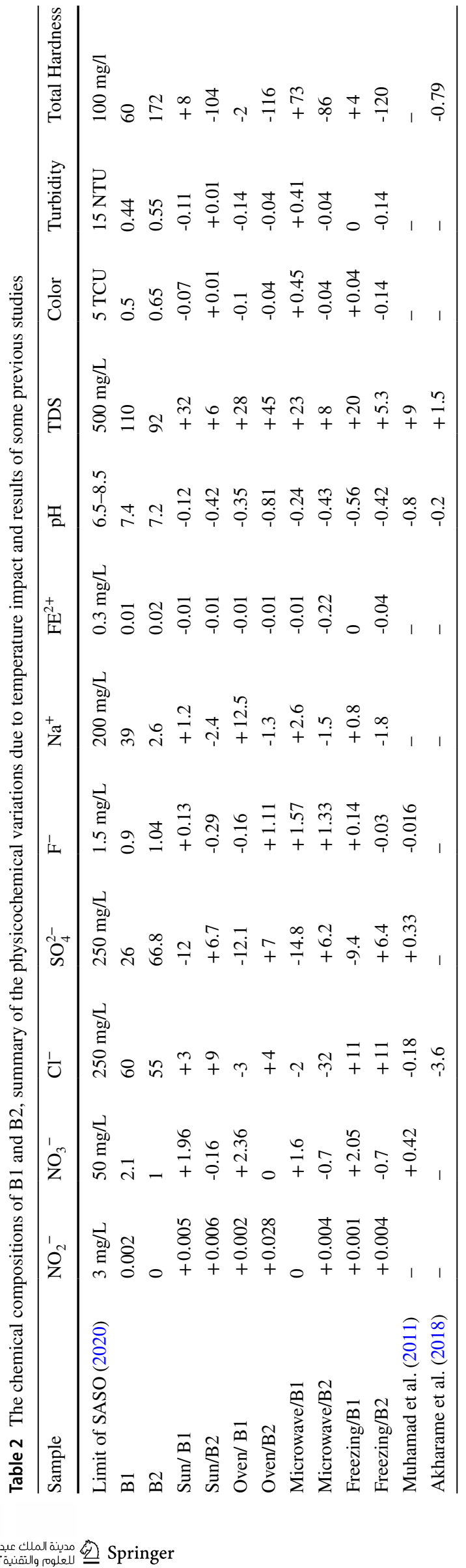

also reduced $\mathrm{pH}$ values to similar values around 6.8 from 7.4 and 7.2, respectively.

Results of color and turbidity measurements showed that for brand B1 there is a slight decrease in these properties from heating water by sun and oven. However, a great increase in both properties due to heating by microwave especially at temperature of $30{ }^{\circ} \mathrm{C}$ as shown in Fig. 2. While for brand $\mathrm{B} 2$ almost there is no significant change due to temperature alteration except at $30^{\circ}$, there is an increase by oven and microwave heating. The microwave heating is always the worst scenario in temperature alteration impacts. This result had been reported also by Cheng et al. (2010). They concluded that heating by microwave can lead to an obvious raise of element release relative to the other heating methods and some even realized a level higher than the allowable levels.

Figure 3 presents hardness and TDS measurements at different heating degrees for brands B1 and B2. Results of hardness measurements for B1 exhibited a slight change due to temperature variation except heating to $70{ }^{\circ} \mathrm{C}$ by microwave, which showed a significant increase. For B2, almost the same except all heating degrees by microwave introduced an increase exceed by $25 \%$ more than that at room temperature. TDS results for both brands including fluctuating temperature from 0 to $70{ }^{\circ} \mathrm{C}$ showed an increase in the property value. Oven and microwave exhibited also the highest impacts. However, all observed values for all water samples were within permissible limits. The obtained trend was alike the result stated by Akharame et al. (2018) and Janan et al. (2012). They reported that the increase in heating and sunlight exposure leads to raise in TDS due to release ions of heavy metals and other physicochemical parameters in water.

\section{Alterations in ions and cations concentrations}

Fluoride concentrations at different heating degrees by using microwave showed an increase with increasing temperature especially at high degrees of 50 and $70{ }^{\circ} \mathrm{C}$ for both brands as seen in Fig. 4. On the other hand, heating by oven exhibited an increase in B2 only and all temperature degrees yielded almost the same concentrations. The acceptable range of Fluoride is $0.6-1.5 \mathrm{mg} / \mathrm{L}$. In the present study, the range of fluoride of analyzed water samples varied between 0.65 and $2.47 \mathrm{mg} / \mathrm{L}$. Thus, there are many samples especially heated above $50{ }^{\circ} \mathrm{C}$ ran higher than the permissible limits. The obtained results are in a contrast with results reported by Muhamad et al. (2011). They concluded that exposure bottled waters to sunlight for above $35{ }^{\circ} \mathrm{C}$ resulted in decreasing the concentration of fluoride and chloride due to acceleration of organic and inorganic compounds leaching from bottled to the content water. On the other hand, chloride concentrations for brands B1 and 

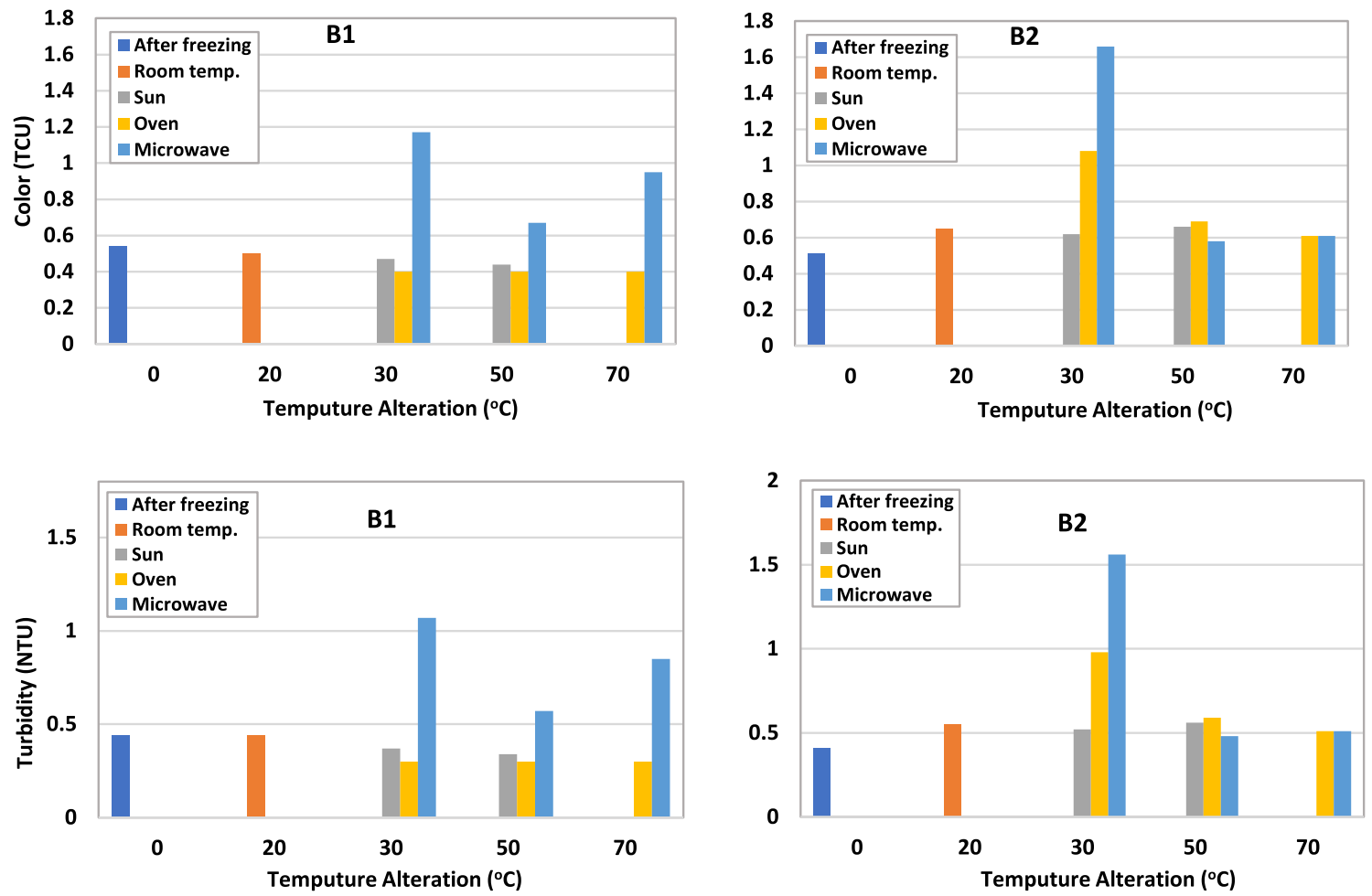

Fig. 2 Color and turbidity measurements at different heating degrees for brands B1 and B2
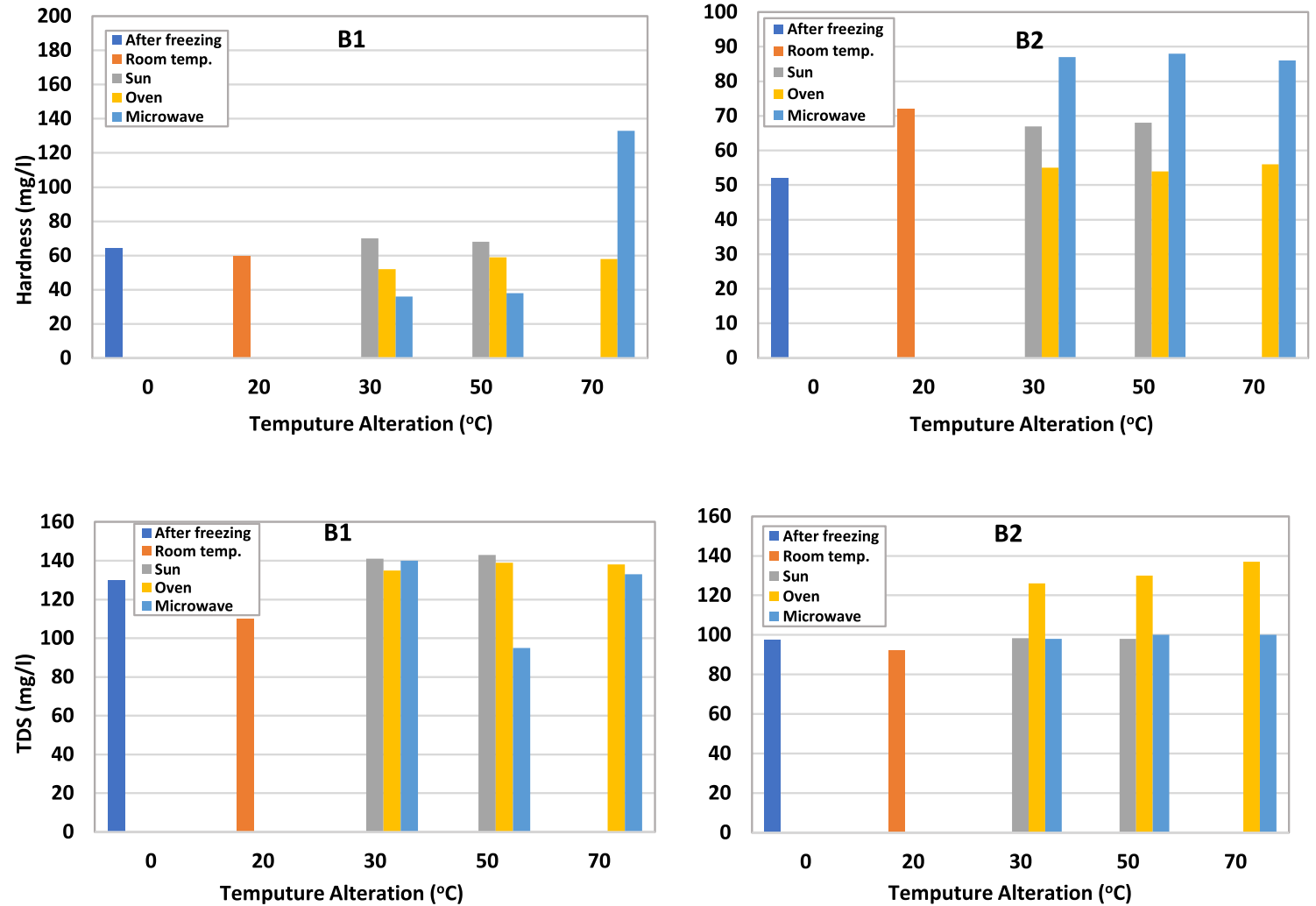

Fig. 3 Hardness and TDS measurements at different heating degrees for brands B1 and B2 
B2 showed a slight increase due to freezing and heating by sun, while a slight decrease by oven heating. However, B2 demonstrated a substantial chronically decrease in chloride levels with increase heating by microwave as shown in Fig. 5, which agree with results reported by Muhamad et al. (2011).

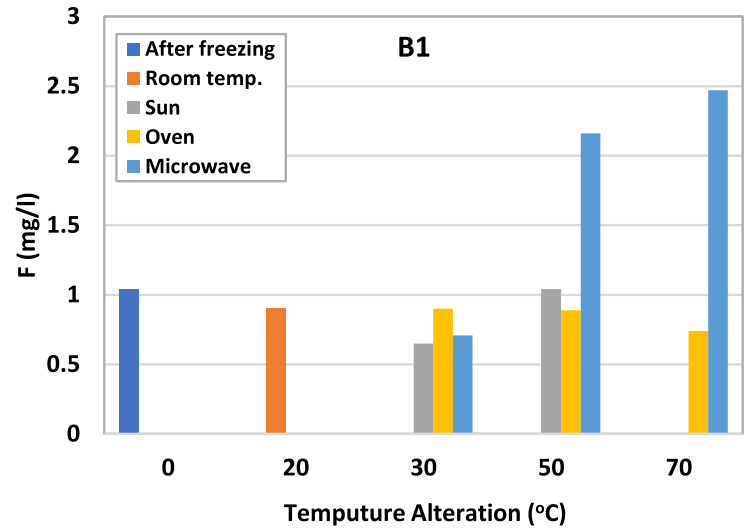

Figure 6 presents sodium concentrations at different heating degrees for B1 and B2. The figure revealed that no notable change or maybe some slight increase was observed for B1 in sodium levels, while a remarkable decrease occurred in B2. For sulfate levels in water presented by Fig. 7, two different behaviors were recorded, B1 marginally decreased while B2 showed substantial increases.

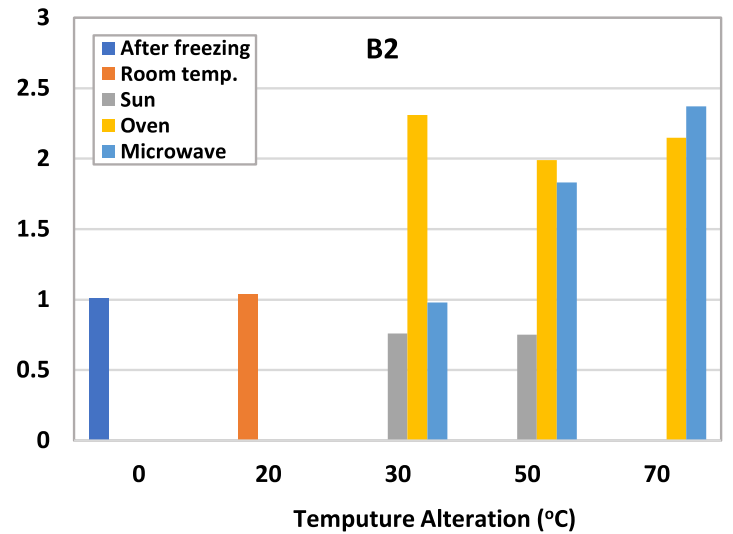

Fig. 4 Fluoride concentrations at different heating degrees for brands B1 and B2
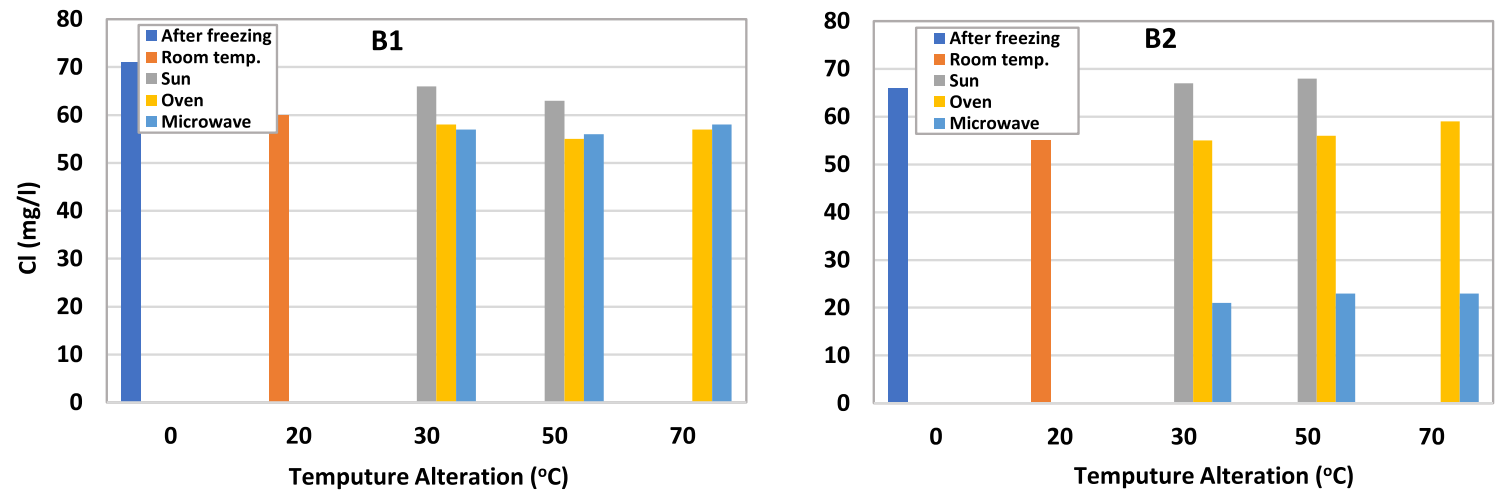

Fig. 5 Chloride concentrations at different heating degrees for brands B1 and B2
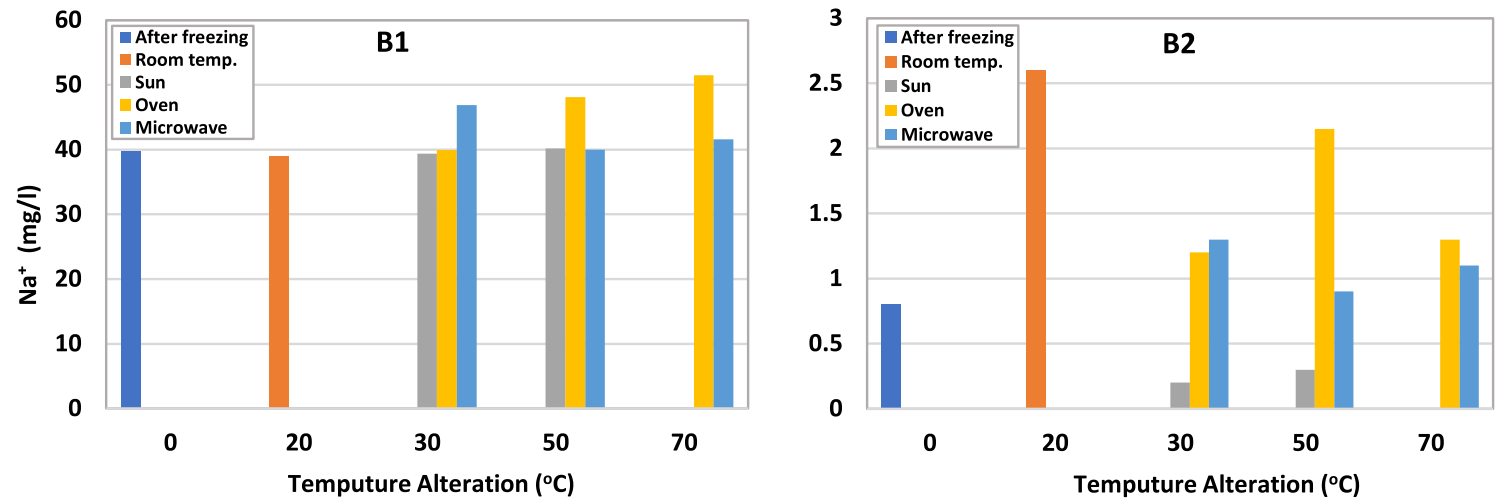

Fig. 6 Sodium concentrations at different heating degrees for brands B1 and B2 

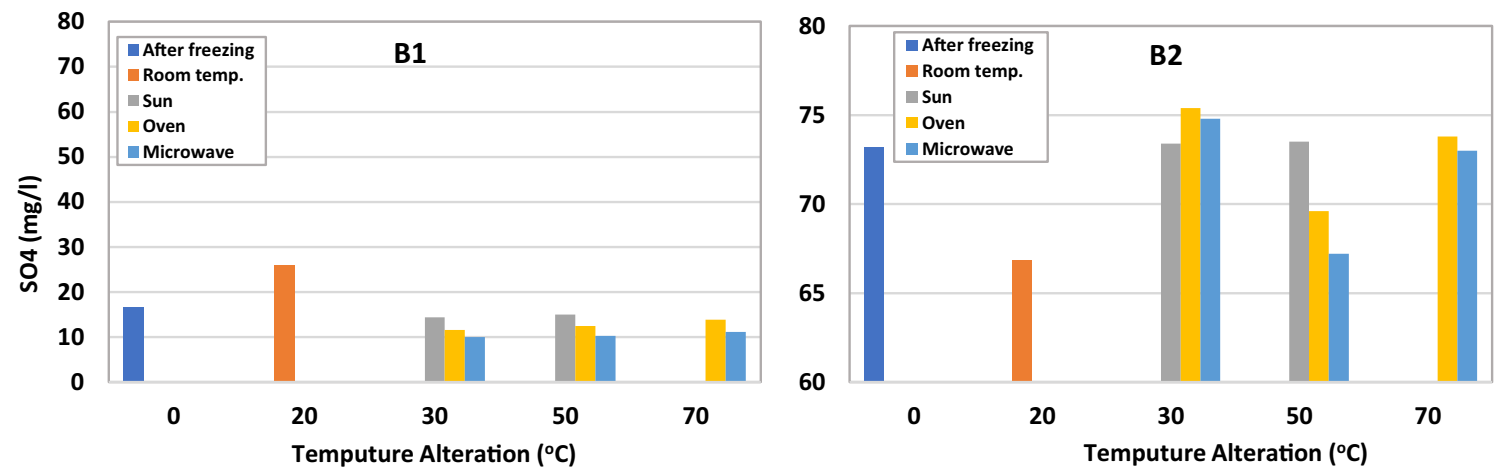

Fig. 7 Sulfate concentrations at different heating degrees for brands B1 and B2

\section{Alterations of heavy metals}

One of the main pollutants that can release to water from plastic bottles is heavy metals. In particular, Antimony is a risky element, which may percolate from the polyethylene terephthalate (PET) bottles into the water. An important key of this study was to examine the release of Antimony and other heavy metals traces in bottled waters under temperature variations. Results showed that heating alteration almost had no effect on Antimony leaching. No notable traces were detected, or it was below the standards in all studied bottled samples. This is in a contrast to results reported by some research works about detecting Antimony in water after exposing the bottles to heating (Cheng et al. 2010; Reimann et al. 2012; Akharame et al. 2018). They confirmed Antinomy leaching in water by increasing temperature especially more than $40{ }^{\circ} \mathrm{C}$. They also reported that cooling may have no activity on the release of this element which similar to obtained results herein.
Perhaps the short exposing time adopted in this study, i.e., maximum one day, for heating samples negatively impact the Antimony release as in the previous studies, they applied heating and exposing to sun for at least 14 days.

Results of this study showed that all levels of heavy metals were very minimal and non-detectable except some small concentrations of Copper and Zinc in B1 and B2 as shown in Fig. 8, while Barium recorded tiny levels in B2 only. This is similar to results reported by others (Cheng et al. 2010; Reimann et al. 2012) for the heavy metals assessment. They revealed that the levels of heavy metals such as Lead, Cadmium and Gold were observed to be less than the detection limit of the used equipment. Furthermore, they showed that Zinc levels in all the bottled water samples were within WHO limits and exposing to sunlight did not yield considerable raise in its concentrations. From Fig. 8, it is worth noted also that oven heating resealed more copper ions into water especially at the highest degree of $70^{\circ} \mathrm{C}$ for $\mathrm{B} 2$ more than $\mathrm{B} 1$ and more than other heating methods.
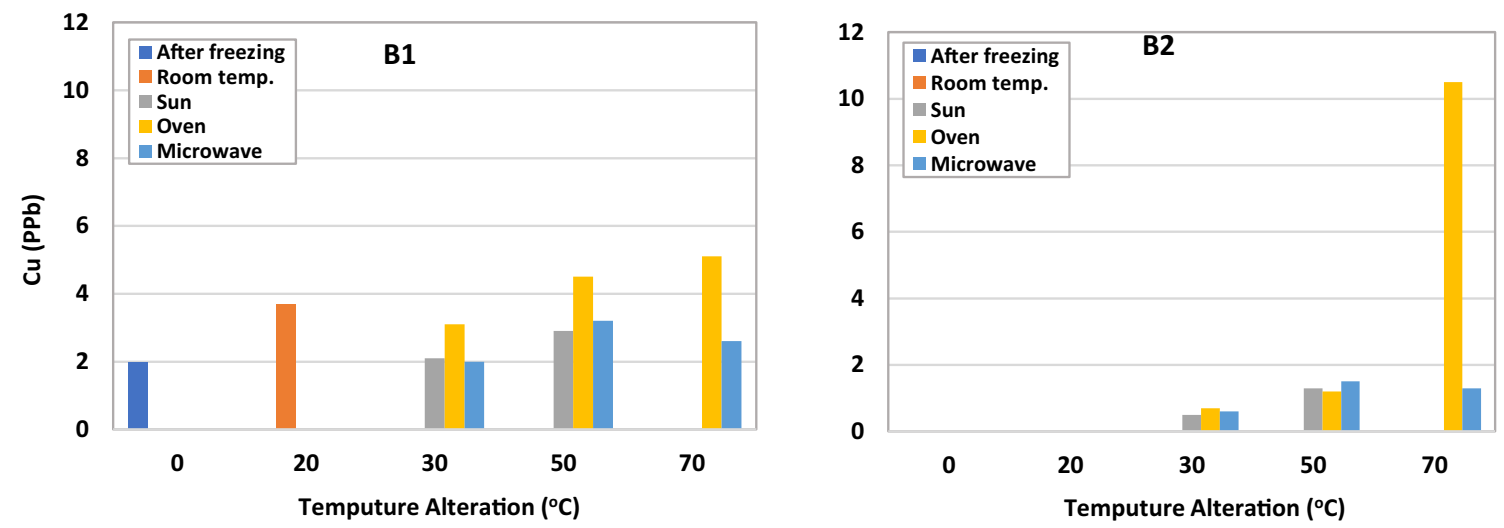

Fig. 8 Copper concentrations at different heating degrees for brands B1 and B2 


\section{Discussion}

The obtained results in this study confirmed the impact of alteration of temperature on physical and chemical properties of drinking water stored in plastic bottles. In addition, the study exhibited the influence of heating methods on the water quality alteration. Table 2 shows a summary of the temperature variation impact on physicochemical properties of the studied brands B1 and B2. The table presents the increase and decrease in the measured properties as positive and negative signs, respectively. The table depicts the impact of the temperature increase, the impact of heating methods, and the variation in the behavior of the two brands. For example, for cooling water to zero inside the plastic bottles and melting it again, the study showed that freezing water reduced the $\mathrm{pH}$ values of brand $\mathrm{B} 1$ and $\mathrm{B} 2$ by $0.56(8 \%)$ and $0.42(5.8 \%)$, respectively. TDS measurements were increased by $20 \mathrm{mg} / \mathrm{l}(18 \%)$ and $5.3 \mathrm{mg} / \mathrm{l}$ (6\%) for B1 and B2, respectively. Results, in the table, also referred to the alteration in behavior of different brands due to the raw materials of the bottles. Annamalai and Namasivayam (2017) revealed that water at $4{ }^{\circ} \mathrm{C}$ expands, and its density increases. As the water expands weak covalent bonds holding polyethersulphone constituents (PEs) break emancipating them into the water. Releasing such constituents would definitely alert TDS measurements. In addition, the variation in the behavior of the two brands comes from the different original compositions as shown in Table 2. There is a distinguished difference between the two brands as clearly shown in the content of $\mathrm{SO}_{4}, \mathrm{Na}, \mathrm{pH}$, TDS, and total hardness. These differences in the chemical compositions played a great role in changing the chemical processes occurred with raising temperature such as precipitation of some elements. It is known that water molecules moving faster when the temperature is higher and speeding up the dissolution reaction. For examples, there is a considerable difference between the total hardness of the two brands as seen in Table 2. B2 having a higher value demonstrated a great redaction after heating by all methods indicating to release calcium and magnesium ions due to cation exchange softening-inorganic, carbonaceous, or organic base exchangers.

For exposing bottled water to sun, the study exhibited a notable change, for instant in B2, sunlight decreased $\mathrm{pH}$ by $0.42(5.8 \%)$ and increased TDS by $6 \mathrm{mg} / \mathrm{l}(6.5 \%)$. Muhamad et al. (2011) reported that exposing bottled waters to sunlight above $35{ }^{\circ} \mathrm{C}$ leads to reducing the $\mathrm{pH}$ values, rising the concentrations of sulfates and nitrates, and raising TDS by $9 \mathrm{mg} / \mathrm{l}$. Akharame et al. (2018) also stated that sunlight heating can decrease $\mathrm{pH}$ value by 0.2 and TDS by $1.5 \mathrm{mg} / \mathrm{l}$ as summarized in the end of Table 2 . On the other hand, for direct heating bottled water by oven and microwave for above $50{ }^{\circ} \mathrm{C}$, the study revealed that there is a higher reduction in $\mathrm{pH}$ and notable increase in TDS and fluoride beyond the permissible values as shown in Table 2. Muhamad et al. (2011) stated that thermal degradation for plastic bottles develops more rapidly at higher temperatures above $45^{\circ} \mathrm{C}$ and accordingly there is a great alteration trend in the values of water physicochemical properties. Reimann et al. (2012) reported also that storage conditions are important for bottled water quality and that storage of water in PET bottles at temperatures above $40{ }^{\circ} \mathrm{C}$ should be avoided. Thus, all these results are alarming findings especially with Al-Zahrani et al. (2017) confirmation that in the Gulf region during normal storage period, the bottled water exposed to a temperature reach to $52{ }^{\circ} \mathrm{C}$. For biological properties, Fecal coliform and total coliform were examined in all bottled water samples. The results of all samples before and after heating for both brands showed zero bacteria.

The study depicted very well the changes come from raising temperature of bottled water under different methods of heating. Most of the previous studies focused on sunlight expose; herein different types of heating were investigated. The main limitation in the study is the short time duration of exposing for heating, however, the results were close to those exposing for up to 14 days as seen in comparing results in Table 2 with some previous studies. The results herein can be useful for regulating the optimum way for transportation and storage of bottle waters. Future work should focus on examining the impact of reiterating heating and cooling on the bottled water quality.

\section{Conclusion}

The obtained results in this study confirmed the impact of alteration of temperature on physical and chemical properties of drinking water stored in plastic bottles. In addition, the study exhibited the influence of heating methods on the water quality alteration. The main findings can be summarized in the following points:

- Temperature alterations caused changes in some physicochemical properties of bottled waters such as decreasing the values of $\mathrm{pH}$ and TDS and increasing values of fluoride and chloride.

- Due to temperature increases of studied bottled waters, the concentration levels of some physiochemical parameters exceeded the permissible values for drinking water.

- With temperature alterations, all levels of heavy metals in bottled waters were very minimal and non-detectable except some small concentrations of copper and zinc

- There are differences in the observed values of physiochemical properties between the bottled water brands 
exposed to the same temperature alterations due to perhaps the disparity in material raw producing the plastic bottles and original contents of water in these brands.

- For heating bottled waters above $50{ }^{\circ} \mathrm{C}$, there is a notable alteration occurred in the physiochemical parameters of the water. Storage conditions are important for bottled water quality, and it should be kept between room temperature and maximum $30{ }^{\circ} \mathrm{C}$.

- The results herein can be useful for regulating the optimum way for transportation and storage of bottled waters. Future work should focus on examining the impact of reiterating heating and cooling on the bottled water quality.

Funding No funding was received for conducting this study.

\section{Declarations}

Conflict of interest The authors declare that they have no conflict of interest.

Ethical approval Authors confirm that the work has been done according to ethical standards of scientific research.

Ethical conduct The principles of ethical and professional conduct have been followed.

Open Access This article is licensed under a Creative Commons Attribution 4.0 International License, which permits use, sharing, adaptation, distribution and reproduction in any medium or format, as long as you give appropriate credit to the original author(s) and the source, provide a link to the Creative Commons licence, and indicate if changes were made. The images or other third party material in this article are included in the article's Creative Commons licence, unless indicated otherwise in a credit line to the material. If material is not included in the article's Creative Commons licence and your intended use is not permitted by statutory regulation or exceeds the permitted use, you will need to obtain permission directly from the copyright holder. To view a copy of this licence, visit http://creativecommons.org/licenses/by/4.0/.

\section{References}

Al-Turk IM, Diab AM (2009) bacteriological drinking water potability at Al-Madinah Al-Mounwwarah in relation to plasmid-linked multidrug-resistance. J Int Environ Appl Sci 4(2):214-230

Al-Zahrani FS, Albaqshi HAA, Alhelal GAM, Mohamed IA, Aga OOP, Abdel-Magid IM (2017) Bottled water quality in KSA. Int J Innov Sci, Eng Technol 4(2):2348-7968 (ISSN (Online))

Akharame MO, Ekhosuehi A, Okolafor FI, Sadoh KA (2018) Effects of sunlight exposure on the quality parameters of bottled water. $\mathrm{J}$ Appl Sci Environ Manage 22(5):769-774
Annamalai J, Namasivayam V (2017) Determination of effect of $\mathrm{pH}$ and storage temperature on leaching of phthalate esters from plastic containers by ultrasound-assisted dispersive liquid-liquid micro-extraction. J Food Meas Charact 11:2222-2232

Bach C, Dauchy X, Chagnon MC, Etienne S (2012) Chemical compounds and toxicological assessments of drinking water stored in polyethylene terephthalate (PET) bottles: A source of controversy reviewed. Water Res 46:571-583

Bolgar M, Hubball J, Groeger J, Meronek S (2008) Handbook for the chemical analysis of plastic and polymer additives. CRC Press Taylor \& Francis Group, LLC (ISBN 978-1-4200-4487-4)

Cheng X, Shi H, Adams CD, Ma Y (2010) Assessment of metal contaminations leaching out from recycling plastic bottles upon treatments. Environ Sci Pollut Res 17:1323-1330

Chilton J (1996) Chapter 9-Groundwater. Water quality assessments - a guide to use of biota, sediments and water in environmental monitoring. ISBN 0-419-21590-5 (HB), 0-419-21600-6 (PB)

Environmental Protection Agency (EPA) (2021) ESAM collaborative analytical methods and protocols for chemistry. https://www.epa. gov/esam/esam-collaborative-analytical-methods-and-protocolschemistry

Guart A, Bono-Blay F, Borrell A, Lacorte S (2014) Effect of bottling and storage on the migration of plastic constituents in Spanish bottled waters. Food Chem 156:73-80

Janan JT, Nihal SH, Bakhtiar AM (2012) Effect of storage condition on some bottled water quality in Erbil City, Kurdistan Region-Iraq. Int J Softw Web Sci 3(1):33-43

Khater AE, Al-Jaloud A, ElTaher A (2014) Quality level of bottled drinking water consumed in Saudi Arabia. J Environ Sci Technol 7(2):90-106

Muhamad SG, Esmail LS, Hasan SH (2011) Effect of storage temperature and sunlight exposure on the physicochemical properties of bottled water in Kurdistan Region-Iraq. J Appl Sci Environ Manage 15(1):147-154

Oyebog SA, Ako AA, Nkeng GE, Suh EC (2012) Hydrogeochemical characteristics of some Cameroon bottled waters, investigated by multivariate statistical analyses. J Geochem Explor 112:118-130

Reimann C, Birke M, Filzmoser P (2012) Temperature-dependent leaching of chemical elements from mineral water bottle materials. Appl Geochem 27:1492-1498

Saudi Standards, Metrology and Quality Organization (SASO) (2020) Water quality standards. https://saso.gov.sa/ar/mediacenter/public_multimedia/Documents/Plastic\%20Bottles.pdf

Taylor-Smith K (2020) Plastic water bottles are a danger to your health. AZoCleantech. https://www.azocleantech.com/article.aspx?Artic leID $=790$. Accessed 14 July 2021

World Health Organization (WHO) (2011) Safe drinking water from desalination. WHO/HSE/WSH/11.03

Zamberlan da Silva ME, Santana RG, Guilhermetti M, Camargo Filho I, Endoc EH, Ueda-Nakamura T, Vataru Nakamura C, Dias Filho BP (2008) Comparison of the bacteriological quality of tap water and bottled mineral water. Int J Hyg Environ Health 211:504-509

Publisher's Note Springer Nature remains neutral with regard to jurisdictional claims in published maps and institutional affiliations. 